Tomasz MŁYNARSKI

Uniwersytet Jagielloński

tomasz.mlynarski@uj.edu.pl

\title{
ROLA PARLAMENTU EUROPEJSKIEGO W KSZTAŁTOWANIU BEZPIECZEŃSTWA ENERGETYCZNEGO UNII EUROPEJSKIEJ
}

ABSTRACT The European Parliament's role in shaping the European Union's energy security

Participation of the European Parliament in the process of energy sector communitarization and providing assurance of Community energy security is enormous due to its position and its legitimacy in European institutions structure. European Parliament - through its participation in the development of energy acquis communautaire, under the ordinary legislative procedure - is a full-fledged entity responsible for the shape of EU's legal order, and the views of MPs interact indirectly on EU law and policies final version. Using indirect legislative initiative, the European Parliament has become also an active creator providing the mandate of EC political initiatives. Consequently, the European Parliament has played an important role at the supranational level in the energy sector communitarization, often acting as a political forum facilitating building of compromises, necessary to deepen the EU's energy policy. It also actively participates in the development of EU energy and climate policy.

Key-words: European Parliament, energy security, European Union

Słowa kluczowe: Parlament Europejski, bezpieczeństwo energetyczne, Unia Europejkka

Darlament Europejski (PE) jest jedną z najważniejszych instytucji Unii Europejskiej 1 (UE). Wpływa na decyzje UE w sposób znaczący, mimo iż jego pozycja w systemie instytucjonalnym Unii jest odmienna od pozycji parlamentów narodowych w sys- 
temach sprawowania władzy państwowej. Kompetencje i funkcje PE zapewniają mu ważną rolę współdecyzyjną w tworzeniu unijnego prawa, a poglądy deputowanych oddziałują w sposób pośredni, a czasem bezpośredni na kształt prawa i polityk UE, także w zakresie współpracy w sektorze energii.

\section{ROLA PARLAMENTU EUROPEJSKIEGO W KSZTAŁTOWANIU ENERGY ACQUIS}

Analizując rolę Parlamentu Europejskiego w rozwoju polityki energetycznej UE, należy zauważyć dwie zasadnicze kwestie. Po pierwsze Traktat z Lizbony (wszedł w życie 1 grudnia 2009 r.) włączył sektor energetyczny w zakres polityk unijnych (art. 4 ust. 2 TFUE, tytuł I: Kategorie i dziedziny kompetencji Unii), wyraźnie określając, że „energia” jest jednym z głównych obszarów kompetencji dzielonej ${ }^{1}$. W ten sposób Komisja Europejska (KE) zyskała uprawnienia do „działania” i inicjowania aktów prawnych w tej dziedzinie. Jest to niezwykle ważne dla rozwoju prawa wtórnego UE w obszarze energetyki, w tworzeniu którego udział Parlamentu Europejskiego jest bardzo istotny.

Po drugie, Traktat z Lizbony stworzył podstawy prawno-traktatowe do działań UE w sektorze energii. Dzięki temu prawo wtórne, ustanowione na podstawie art. 114 ust. 1 TFUE odgrywa ważną rolę w rozwijaniu kompetencji Wspólnoty w dziedzinie energii ${ }^{2}$.

Stworzenie podstaw prawno-traktatowych dla polityki energetycznej w odrębnym tytule (art. 194 TFUE, tytuł XXI: Energetyka) pozwoliło w pełni włączyć Parlament Europejski jako pełnoprawny podmiot odpowiadający za współudział w kształtowaniu unijnego porządku prawnego w omawianym zakresie.

Równocześnie Traktat z Lizbony zwiększył liczbę dziedzin, w których Parlament Europejski decyduje na równi z Radą UE w procesie tworzenia unijnego prawa. Artykuł 194 ust. 2 TFUE określił traktatową podstawę prawną w obrębie zwykłej procedury ustawodawczej dla przyjmowania w ramach unijnego acquis regulacji prawa pochodnego UE, umożliwiających realizację celów polityki energetycznej³. Polityka energetyczna (obok wielu innych obszarów) znalazła się w obrębie procedury współdecyzji (zwykła procedura ustawodawcza), w której Parlament Europejski dzieli równo

Cele określone w art. 194 ust. 1 TFUE zostały w istocie rozpowszechnione w całym traktacie w różnych obszarach polityk. Unia Europejska uzyskała wpływ na politykę energetyczną przez swoje kompetencje dotyczące „rynku wewnętrznego”, „sieci transeuropejskich”, „środowiska”. Oznacza to, że polityka energetyczna UE w rzeczywistości znalazła się pod wpływem innych obszarów współpracy. W konsekwencji „kompetencja wspólna” w dziedzinie energii jest realizowana w sposób pośredni przez inne polityki.

2 Art. 114 ust. 1 TFUE: [...] Parlament Europejski i Rada, stanowiac zgodnie ze zwykta procedura ustawodawcza i po konsultacji z Komitetem Ekonomiczno-Spotecznym, przyjmują środki dotyczace zbliżenia przepisów ustawowych, wykonawczych i administracyjnych Państw Cztonkowskich, które mają na celu ustanowienie i funkcjonowanie rynku wewnętrznego.

3 Działania, które obejmują „charakter fiskalny”, będą ustalone przez Radę jednomyślnie. 
władzę z Radą UE w przyjmowaniu unijnych aktów prawnych. Oznacza to, że w większości przypadków, zanim unijny akt prawny zacznie obowiązywać w państwach członkowskich, Parlament i Rada muszą uzgodnić jego treść. Ponadto Parlament Europejski, choć nie ma uprawnień do przygotowania samodzielnie projektów prawa wspólnotowego, może zwrócić się większością głosów do Komisji o przedłożenie propozycji legislacyjnych w kwestiach, co do których uważa on, że akt Unii jest niezbędny w celu wykonania traktatów (art. 225 TFUE). Jest to pośrednia inicjatywa ustawodawcza, czyli tzw. prawo inicjatywy politycznej.

Parlament Europejski, pełniąc funkcje ustawodawcze, posiada szerokie spektrum instrumentów oddziaływania na uwspólnotowienie sektora energetycznego (udział w procedurze prawotwórczej, debaty parlamentarne). Komisja ITRE (The Committee on Industry, Research and Energy - przemysł, badania i energia) uczestniczy w procesie legislacyjnym w zakresie unijnych środków dotyczących ogólnie polityki energetycznej, bezpieczeństwa zaopatrzenia w energię i efektywności energetycznej, w tym także tworzenia i rozwoju sieci transeuropejskich w sektorze infrastruktury energetyki i bezpieczeństwa nuklearnego (może przygotować sprawozdanie dotyczące konkretnych kwestii i przedstawić Parlamentowi projekt rezolucji w sprawie legislacyjnej lub wszystkich pozostałych, jak np. raporty, zalecenia). Podobną funkcję spełnia komisja ENVI (The Committee on Environment, Public Health and Food Safety - ochrona środowiska naturalnego, zdrowie publiczne i bezpieczeństwo żywności) w zakresie klimatycznych aspektów polityki energetycznej.

\section{UDZIAŁ PARLAMENTU EUROPEJSKIEGO W KREOWANIU POLITYKI ENERGETYCZNO-KLIMATYCZNEJ UE}

Polityka energetyczna UE opiera się na trzech filarach: 1) bezpieczeństwo dostaw, 2) rynek wewnętrzny oraz 3) polityka klimatyczna (art. 194 TFUE). Rola PE w tym pierwszym zakresie jest bardzo ograniczona ze względu na tradycyjnie okrojone kompetencje instytucji UE w zakresie wspólnej polityki zagranicznej i bezpieczeństwa (WPZiB) i może wyrażać się w formie inicjatyw politycznych. Zupełnie inaczej przedstawia się rola PE w polityce energetycznej UE w odniesieniu do rynku wewnętrznego poprzez współtworzenie aktów prawa UE.

\section{1) Rola Parlamentu Europejskiego w zapewnieniu bezpieczeństwa dostaw i rozwoju transeuropejskiej infrastruktury przesyłu surowców}

Rola PE w zakresie wpływu na pogłębienie zewnętrznego wymiaru współpracy energetycznej UE jest bardzo ograniczona i sprowadza się głównie do wyrażenia stanowisk w określonych kwestiach. Przykładem jest choćby Rezolucja Parlamentu Europejskiego z dnia 26 września 2007 r. w sprawie wspólnej europejskiej polityki zagranicznej w dziedzinie energetyki, która wyraziła oczekiwanie Parlamentu odnośnie do przyjęcia przez Unię odpowiedniej podstawy traktatowej do prowadzenia polityki ener- 
getycznej i bezpieczeństwa energetycznego ${ }^{4}$. Ponadto 17 września 2009 r., w związku z kryzysem gazowym Rosja-Ukraina (ze stycznia 2009 r.) Parlament Europejski przyjął rezolucję wzywającą władze krajów członkowskich oraz instytucje unijne do zwiększenia wysiłków na rzecz uniknięcia zakłóceń w dostawach gazus. W ten sposób europosłowie zaapelowali o stworzenie wspólnej europejskiej polityki bezpieczeństwa energetycznego.

Kryzys gazowy uruchomił także prace nad regulacją poprawiającą bezpieczeństwo gazowe państw członkowskich. W efekcie w październiku 2010 r. przyjęte zostało Rozporządzenie Parlamentu Europejskiego i Rady nr 994/2010 w sprawie środków zapewniających bezpieczeństwo dostaw gazu ziemnego ${ }^{6}$. Dzięki wpływowi Parlamentu Europejskiego jest ono dużo bardziej ambitne niż pierwotna wersja projektu $\mathrm{KE}^{7}$. Rozporządzenie wprawdzie odnosi się do rynku wewnętrznego UE (jego angielska nazwa to Security of Supply - SOS), w praktyce jednak wzmacnia bezpieczeństwo energetyczne państw członkowskich UE. Rozporządzenie ustanawia bowiem mechanizmy zapobiegania i reagowania w sytuacjach kryzysowych, przez co pośrednio ma odniesienie do dostaw z zewnątrz ${ }^{8}$. Wprowadzenie stanu kryzysowego należeć będzie do KE, która może na wniosek jednego państwa członkowskiego i musi na wniosek dwóch państw członkowskich ogłosić stan kryzysowy na poziomie UE lub w odniesieniu do danego regionu.

Ponadto rozporządzenie zakazuje zawierania umów o dostawę surowca z tzw. klauzulą przeznaczenia (co umożliwi reeksport gazu) ${ }^{9}$. Bezpośrednim skutkiem tego rozwiązania dla Polski była renegocjacja umowy gazowej z Rosją w październiku 2010 r., urealniająca termin związania umową (z 2037 r. do 2022 r.) oraz wymuszająca wykreślenie zakazu reeksportu gazu z Rosji. Obie kwestie są bardzo korzystne dla Polski, albowiem przez wiele lat Gazprom gwarantował sobie przywileje różnymi klauzulami take-or-pay oraz klauzulą przeznaczenia (zakaz odsprzedaży nadwyżki). W praktyce klauzule niedozwolone czyniły z Gazpromu podwójnego monopolistę ${ }^{10}$. Związanie Polski długoletnim kontraktem dostaw gazu na warunkach Gazpromu mogłoby

4 Rezolucja Parlamentu Europejskiego z dnia 26 września 2007 r. w sprawie wspólnej europejskiej polityki zagranicznej $w$ dziedzinie energetyki (2007/2000(INI)).

5 Rezolucja Parlamentu Europejskiego z dnia 17 września 2009 r. w sprawie zewnętrznych aspektów bezpieczeństwa energetycznego, Dz. U. 2008, 28 VIII, C 219 E.

6 Rozporządzenie (UE) 994/2010 z dnia 20 października 2010 roku w sprawie środków zapewniajacych bezpieczeństwo dostaw gazu ziemnego i uchylenia dyrektywy Rady 2004/67/WE, L 295/1, 12 XI 2010.

7 Propozycja KE przesłana do PE uzależniała możliwość ogłoszenia stanu nadzwyczajnego od utraty co najmniej 10\% dziennych dostaw gazu, liczonych dla wszystkich krajów unijnych.

8 Rozporządzenie ustanawia tzw. grupy regionalne państw, zobowiązane do wzajemnej pomocy w zakresie dostaw gazu, i wpłynie na budowę nowych interkonektorów gazowych lub modernizacji istniejących w celu przesyłu gazu w sytuacjach kryzysowych.

9 Motyw 45 Rozporządzenia 994/2010; por.: Oświadczenie Komisji w sprawie konkurencji w odniesieniu do motywu 45, [online] http://www.europarl.europa.eu/sides/getDoc.do?pubRef=-//EP// TEXT+TA+P7-TA-2010-0322+0+DOC+XML+V0//PL, 30 VIII 2014.

10 Na przykład zgodnie z art. 8 polsko-rosyjskiego międzyrządowego porozumienia z 1993 r. gaz ziemny dostarczany z Federacji Rosyjskiej do Polski nie mógt być reeksportowany do krajów trzecich. 
w dłuższej perspektywie podważyć opłacalność gazoportu w Świnoujściu oraz technologii shale gas w Polsce.

Regulacja kładzie także nacisk na rozbudowę infrastruktury umożliwiającej odwrócenie przepływu gazu oraz zwiększenie pojemności magazynów. Równolegle wzmocnienie rynku wewnętrznego gazu będzie się odbywać przez systematyczne tworzenie europejskich hubów i węzłów gazowych. Rozwinie to wewnętrzny system handlu gazem oraz będzie sprzyjać przepływowi surowca między subregionami (infrastruktura przesyłowa między hubami, a nie między siecią dystrybucji międzypaństwowej $)^{11}$.

Na początku 2011 r., wspierając proces uwspólnotowienia współpracy energetycznej, Komisja zaproponowała mechanizm wymiany informacji dotyczących umów międzyrządowych zawieranych między państwami członkowskimi a państwami trzecimi w zakresie dostaw surowców strategicznych celem poprawy koordynacji na wewnętrznym rynku energii ${ }^{12}$. Proponowany mechanizm rozszerzał procedurę notyfikacyjną stosowaną już w odniesieniu do umów gazowych (obowiązek raportowania umów gazowych dla państw członkowskich ${ }^{13}$. Nowe rozwiązanie wzmacnia i rozszerza obowiązek raportowania o umowy międzyrządowe, które mogą mieć wpływ na rynek wewnętrzny energii lub na państwa członkowskie ${ }^{14}$. Unijny komisarz ds. energii Günther Oettinger wyjaśnial: Proponujemy mechanizm wczesnej i doktadnej wymiany informacji [...] dla wszystkich porozumień energetycznych, niezależnie od tego, czy mówimy o gazie, ropie, energii elektrycznej lub odnawialnych źródtach energii ${ }^{15}$. I dalej: Państwa cztonkowskie będa zobowiazane do informowania nas o istniejacych [umowach - T.M.] oraz tych negocjowanych ${ }^{16}$. W ten sposób KE uzyskała uprawnienia monitorowania wszystkich międzyrządowych porozumień dotyczących energii między państwami członkowskimi UE a państwami trzecimi. Stworzenie mechanizmu wymiany informacji na poziomie UE przed rozpoczęciem negocjacji z państwami trzecimi i po ich zakończeniu zwiększy siłę przetargową w negocjacji umów dostaw surowców. Mechanizm został zatwierdzony w nawiązaniu do art. 194 TFUE w październiku 2012 r., decyzją PE i Rady, co obrazuje proces postępującej europeizacji zewnętrznego

11 Por.: L. Parmigiani, Gas Routes to Europe. Real Needs and Political Jockeying, Institut Français des Relations Internationales, 16 IV 2012, s. 19, [online] http://www.ifri.org/sites/default/files/atoms/files/ actuellelppipelinesvf20120413.pdf, 16 VII 2015.

12 The EU Energy Policy. Engaging with Partners beyond Our Borders, COM (2011) 539 final, Brussels, 7 IX 2011.

13 Art. 13 pkt. 6 Rozporządzenia (UE) 994/2010 Wymiana informacji: [...] państwa cztonkowskie przekazują Komisji istniejące umowy międzyrządowe zawarte z państwami trzecimi, które maja wptyw na rozwój infrastruktury gazowniczej i dostawy gazu. Przy zawieraniu nowych umów międzyrządowych z państwami trzecimi, które maja taki wptyw, państwa cztonkowskie informują Komisje [...].

14 Do komunikatu został dołączony projekt Decyzji Parlamentu Europejskiego i Rady ustanawiającej mechanizm wymiany informacji $w$ odniesieniu do umów międzyrządowych $w$ dziedzinie energii między państwami cztonkowskimi a państwami trzecimi, COM (2011) 540, 2011/0238 (COD), Bruksela, 7 IX 2011.

15 S. van Renssen, External Energy Policy. Brussels Takes Charge, „European Energy Review” 2011, 12 IX.

16 Tamże. 
wymiaru wspólnej polityki energetycznej Unii ${ }^{17}$. Nowe rozwiązanie istotnie wzmacnia kompetencje KE w zakresie polityki energetycznej, choć nie tworzy jeszcze uprawnień dla negocjowania przez KE umów z dostawcami ${ }^{18}$.

Innym przykładem aktywności Parlamentu Europejskiego jest Rezolucja z dnia 12 czerwca 2012 r. w sprawie nawiązania współpracy w zakresie polityki energetycznej z partnerami spoza UE: podejście strategiczne do bezpiecznych, zrównoważonych i konkurencyjnych dostaw energii ${ }^{19}$.

Jednym z elementów bezpieczeństwa energetycznego jest zapewnienie nieprzerwanego przesyłu surowców. Wraz z postępem idei stworzenia wspólnego rynku Komisja Europejska zaczęła przywiązywać większą wagę do fizycznego scalania rynków „klamrami rurociągów/interkonektorów”. W Komunikacie do PE i Rady z 19 stycznia 1994 r. (Community guidelines on trans-european energy networks) Komisja Europejska podkreśliła, że rozwój sieci energetycznych jest wciąż ksztattowany przez wymiar narodowy celem osiagnięcia niezależności na poziomie kraju, co nie jest kompatybilne z postępem w kierunku [...] budowy wspólnego rynku ${ }^{20}$. Podejmując działania w zakresie rozwoju transeuropejskich sieci energetycznych, Decyzją 1047/97/WE Parlamentu i Rady z 29 maja 1997 r. przyjęto serię wytycznych dotyczących transeuropejskich energetycznych sieci przesyłowych (w tym załącznik obejmujący listę 74 projektów transgranicznych wspólnego zainteresowania) ${ }^{21}$. Podobnie Decyzja 1364/2006/WE Parlamentu Europejskiego i Rady z 6 września 2006 r. o wsparciu i rozwoju transeuropejskich projektów energetycznych określa wytyczne dla projektów będących przedmiotem wspólnego zainteresowania oraz projektów priorytetowych (projects of European interest) w zakresie transeuropejskich sieci elektroenergetycznych i gazowych (Trans-European Energy Networks - TEN-E) ${ }^{22}$. Kolejny dokument to Rezolucja z dnia 12 marca 2013 r. w spra-

17 Decyzja Parlamentu Europejskiego i Rady nr 994/2012/UE z dnia 25 października 2012 r. w sprawie ustanowienia mechanizmu wymiany informacji $w$ odniesieniu do umów międzyrządowych $w$ dziedzinie energii między państwami cztonkowskimi a państwami trzecimi, Dz. U. UE 2012, 27 X, L 299/13.

18 Komisja zapewnia państwom członkowskim wsparcie prawne w trakcie negocjowania umów, które mają bezpośredni skutego dla rynku wewnętrznego, w szczególnych przypadkach może sporządzić ocenę ex-ante dotyczącą zgodności przyszłej umowy międzyrządowej z przepisami UE.

19 European Parliament resolution of 12 June 2012 on Engaging in energy policy cooperation with partners beyond our borders. A strategic approach to secure, sustainable and competitive energy supply (2012/2029(INI)), [online] http://www.europarl.europa.eu/sides/getDoc.do?pubRef=-//EP// TEXT+TA+P7-TA-2012-0238+0+DOC+XML+V0//EN, 27 VII 2015.

20 Community guidelines on trans-European energy networks, COM (93) 685 final, Brussels, 19 I 1994; Proposal for a EP and Council decision 94/0009 (COD) laying down a series of guidelines on trans-European energy networks; Proposal for a Council decision 94/0010 (SYN) laying down a series of measures aimed at creating a more favourable context for the development of trans-European networks in the energy sector, s. 4 .

21 Decision no 1047/97/EC of the European Parliament and of the Council of 29 May 1997 amending Decision No 1254/96/EC laying down a series of guidelines for trans-European energy networks, Official Journal, L 152, 11 VI 1997.

22 Decision no 1364/2006/EC of the European Parliament and of the Council of 6 September 2006 laying down guidelines for trans-European energy networks and repealing Decision 96/391/EC and Decision no 1229/2003/EC, Official Journal, L 262, 22 IX 2006. 
wie wniosku dotyczącego rozporządzenia Parlamentu Europejskiego i Rady w sprawie wytycznych dotyczących transeuropejskiej infrastruktury energetycznej i uchylającego decyzję nr 1364/2006/WE.

Osobna sprawa to istotne prerogatywy budżetowe Parlamentu Europejskiego, które mają wpływ na finansowanie sieci transeuropejskich. Wraz z wejściem w życie traktatu lizbońskiego parlament uzyskał wpływ na całość unijnego budżetu i pozostaje jednym z dwóch organów władzy budżetowej (art. 314 TFUE). PE uczestniczy w procedurze budżetowej od etapu przygotowania, zwłaszcza w ustalaniu ogólnych wytycznych i charakteru wydatków, uchwala budżet i kontroluje jego wykonanie (art. 318 TFUE). Wreszcie Parlament musi zatwierdzić wieloletnie ramy finansowe (art. 312 TFUE). Prerogatywy budżetowe omawianej instytucji UE w kwestiach finansowych wpływają zatem na decyzje finansowania sieci transeuropejskich. W lipcu 2011 r. Parlament przyjął Rezolucję w sprawie priorytetów w odniesieniu do infrastruktury energetycznej na 2020 r. i w dalszej perspektywie ${ }^{23}$. Po konsultacjach KE z przedstawicielami Parlamentu Europejskiego w listopadzie 2013 r., w grudniu przyjęto Rozporządzenie Parlamentu i Rady (UE) nr 1316/2013 ustanawiające instrument finansowy „Łącząc Europę” służący wsparciu kluczowych projektów budowy i modernizacji infrastruktury m.in. w obszarze energetyki (np. sieci transgraniczne).

\section{2) Rola Parlamentu Europejskiego w liberalizacji sektora energetycznego i tworzeniu podstaw wspólnego rynku energii}

Na początku lat 90. XX w. KE przyspieszyła tworzenie wspólnego rynku energii elektrycznej i gazu ziemnego, rozpoznając, że ukończenie internal energy market (IEM) nadal ograniczane jest przez ${ }^{24}$ :

- wysoki poziom koncentracji, faworyzujący niektóre dominujące firmy,

- wysoki stopnień integracji pionowej przedsiębiorstw,

- rozdrobniony rynek europejski funkcjonujący w granicach państw narodowych.

Parlament Europejski aktywnie angażował się na rzecz liberalizacji rynku energetycznego, o czym świadczy przyjęcie ${ }^{25}$ :

- Dyrektywy 96/92/WE Parlamentu Europejskiego i Rady z dnia 19 grudnia 1996 r. dotyczącej wspólnych zasad rynku wewnętrznego energii elektrycznej;

- Dyrektywy 98/30/WE Parlamentu Europejskiego i Rady z dnia 22 czerwca 1998 r. dotyczącej wspólnych zasad rynku wewnętrznego gazu ziemnego.

23 Rezolucja Parlamentu Europejskiego $z$ dnia 5 lipca 2011 r. w sprawie priorytetów w odniesieniu do infrastruktury energetycznej na 2020 r. i $w$ dalszej perspektywie (2011/2034(INI)).

24 Por.: M. Derdevet, L'Europe en panne d'énergie. Pour une politique énergétique commune, Paris 2009, s. 105.

25 Directive 96/92/EC of the European Parliament and of the Council of 19 December 1996 concerning common rules for the internal market in electricity, Official Journal, L 027, 30 I 1997; Directive 98/30/ EC of the European Parliament and of the Council of 22 June 1998 concerning common rules for the internal market in natural gas, Official Journal, L 204, 21 VII 1998. 
Dyrektywy (dotycząca elektryczności - 96/92/WE, zwana też dyrektywą IEM; oraz dotycząca gazu - 98/30/WE) zostały oparte na trzech zasadach ${ }^{26}$ :

- wprowadzenie konkurencji z jednoczesnym respektowaniem celów usług publicznych,

- stopniowe wprowadzenie reguł konkurencji na rynki gazu i prądu elektrycznego, by dać wystarczający czas dla przemysłu na dostosowanie się do nowych uwarunkowań rynkowych,

- stworzenie ram (nie ścisłych regulacji) dla jednolitego rynku, z pozostawieniem państwom członkowskim wyboru sposobów realizacji nakreślonego celu.

Dyrektywy z lat 1996 i 1998 zakładały progresywne otwarcie na konkurencję (w latach 1997-2003 dla elektryczności, a w latach 2000-2008 dla gazu). Przewidywały ograniczony dostęp stron trzecich (do sieci) pod kontrolą krajowego regulatora. W następnym etapie ustanawiania wspólnych zasad rynku energetycznego Komisja stopniowo przesunęła nacisk z liberalizacji na scalanie rynków energetycznych we wspólny rynek energii ${ }^{27}$. Drugi pakiet energetyczny, przyjęty w 2003 r., znacznie pogłębiał zakres liberalizacji rynków krajowych ${ }^{28}$ :

- Dyrektywa 2003/54/WE Parlamentu Europejskiego i Rady z dnia 26 czerwca 2003 r. dotycząca wspólnych zasad rynku wewnętrznego energii elektrycznej i uchylająca dyrektywę 96/92/WE;

- Dyrektywa 2003/55/WE Parlamentu Europejskiego i Rady z dnia 26 czerwca 2003 r. dotycząca wspólnych zasad rynku wewnętrznego gazu ziemnego i uchylająca dyrektywę 98/30/WE.

Drugi pakiet liberalizacyjny zobowiązał do zapewnienia (zarówno w sektorze energii elektrycznej [art. 20 ust. 1 dyrektywy 2003/54/WE], jak i gazu ziemnego [art. 18 dyrektywy 2003/54/WE]) tak zwanej zasady TPA (Third Party Access), według której odbiorcy końcowi mogą swobodnie wybierać dostawcę energii, który zaoferuje najlepsze warunki sprzedaży, nadal korzystając z sieci przesyłowej dotychczasowego operatora systemu przesyłowego (OSP) i operatora systemu dystrybucyjnego (OSD). Jednocześnie zasada TPA nałożyła na przedsiębiorstwa sieciowe, których przedmiotem działalności jest przesyłanie i dystrybucja energii (elektrycznej i gazu), obowiązek udostępnienia (za opłatą) swojej sieci na rzecz innych podmiotów, umożliwiając nieskrępowany przesył energii swoimi sieciami od dostawcy do odbiorcy. Dzięki polityce liberalizacji i rozwiązaniom przyjętym w ramach tak zwanego II pakietu nowi dostawcy gazu

26 On the state of liberalisation of the energy markets, Second Report from the Commission to the Council and the European Parliament, COM (1999) 198 final, Brussels, 4 V 1999, s. 5.

27 Communication from the commission to the council and the European Parliament Completing the internal energy market Proposal for a Directive of the European Parliament and of The Council amending Directives 96/92/EC and 98/30/EC concerning common rules for the internal market in electricity and natural gas, COM (2001) 125 final, Brussels, 13 III 2001.

Directive 2003/54/EC of the European Parliament and of the Council of 26 June 2003 concerning common rules for the internal market in electricity, Official Journal, L 176/37, 15 VII 2003; Directive 2003/55/EC of the European Parliament and of the Council of 26 June 2003 concerning common rules for the internal market in natural gas, Official Journal, L 176/57, 15 VII 2003. Dyrektywy weszly w życie 4 sierpnia $2003 \mathrm{r}$. 
i energii elektrycznej mogli wejść na rynki państw członkowskich, podczas gdy konsumenci (przemysłowi od 1 lipca 2004 r., a gospodarstwa domowe od 1 lipca 2007 r.) mogli wybierać swojego dostawcę ${ }^{29}$. Nowe przepisy zobowiązały zintegrowane pionowo przedsiębiorstwa energetyczne do podzielenia się na odrębne podmioty: operatora sieci oraz producenta/dostawcę energii. Mogły one być powiązane kapitałowo, lecz musiały być rozdzielone pod względem formy prawnej, organizacyjnej i podejmowania decyzji inwestycyjnych ${ }^{30}$.

W odniesieniu do rynku gazu założenia były analogiczne do tych, które obowiązywały dla rynku energii elektrycznej, to znaczy nastąpiło prawne wydzielenie (bez rozdziału własności) operatorów systemu (przesyłowego i dystrybucji) od producentów/dostawców energii z możliwością swobodnego wyboru dostawcy przez użytkowników sieci.

Kolejnym krokiem było przyjęcie III pakietu energetycznego (Third Internal Energy Market Package), który koncentrował się na tak zwanym rozdzieleniu własnościowym (ownership unbundling) w pionowo zintegrowanych strukturach OSP oraz OSD ${ }^{31}$. Rozdział własności stał się warunkiem skutecznej polityki energetycznej w Europie (dyrektywa elektroenergetyczna 2009/72/WE ${ }^{32}$ i dyrektywa gazowa 2009/73/WE $\left.{ }^{33}\right)$.

Na każdym etapie reform Parlament Europejski niezmiennie wyrażał swoje zdecydowane poparcie dla liberalizacji wspólnego rynku energii. Trzeci pakiet dyrektyw i rozporządzeń wszedł w życie 3 marca $2011 \mathrm{r} .{ }^{34}$ Oprócz rozdziału produkcji (dostaw) od przesyłu wzmocnił on uprawnienia i niezależność krajowych organów regulacyjnych nadzorujących funkcjonowanie rynków energii elektrycznej i gazu oraz powołał niezależny organ - Agencję ds. Współpracy Organów Regulacji Energetyki (ACER) koordynujący pracę regulatorów krajowych ${ }^{35}$.

29 Do dnia 1 lipca 2007 r. konsumenci w większości przypadków mogli kupować energię wyłącznie na rynku regulowanym.

30 Rozporzadzenie (WE) nr 1228/2003 Parlamentu Europejskiego i Rady z dnia 26 czerwca 2003 r. wsprawie warunków dostępu do sieci w odniesieniu do transgranicznej wymiany energii elektrycznej, L 176/1, 15 VII 2003; Rozporzadzenie (WE) nr 1775/2005 Parlamentu Europejskiego i Rady z dnia 28 września 2005 r, w sprawie warunków dostępu do sieci przesytowych gazu ziemnego, L 289/1, 3 XI 2005.

31 Unbundling (rozdzielenie) oznacza wydzielenie z przedsiębiorstwa zintegrowanego pionowo (tzn. prowadzącego działalność przesyłową lub dystrybucyjną oraz działalność z zakresu produkcji lub dostaw) działalności polegającej na przesyle, magazynowaniu i dystrybucji.

32 Directive 2009/72/EC of the European Parliament and of the Council of 13 July 2009 concerning common rules for the internal market in electricity and repealing Directive 2003/54/EC, Official Journal of the European Union, L 211/5, 14 VIII 2009.

33 Directive 2009/73/EC of the European Parliament and of the Council of 13 July 2009 concerning common rules for the internal market in natural gas and repealing Directive 2003/55/EC, Official Journal of the European Union, L 211/94, 14 VIII 2009.

34 Przepisy dotyczące unbundlingu weszły w życie z dniem 3 marca 2012 r.

35 Akty prawne w ramach trzeciego pakietu energetycznego: Dyrektywa Parlamentu Europejskiego i Rady 2009/72/WE z dnia 13 lipca 2009 r. dotycząca wspólnych zasad rynku wewnętrznego energii elektrycznej i uchylająca dyrektywę 2003/54/WE; Dyrektywa Parlamentu Europejskiego i Rady 
Trzeci pakiet pomógł uczynić ważny krok w kierunku dokończenia budowy rynku wewnętrznego energii oraz transgranicznego handlu energią. Przyjęte w ramach niego rozporządzenia pozwalają na planowanie na poziomie europejskim rozwoju sieci i stwarzają ramy instytucjonalne do prowadzenia europejskiej polityki energetycznej w ramach utworzonej agencji regulatorów ACER ${ }^{36}$.

Dnia 20 czerwca 2013 r. Komisja ITRE Parlamentu Europejskiego przyjęła raport „Uruchomienie wewnętrznego rynku energii”. Dokument jest odpowiedzią PE na komunikat Komisji Europejskiej z listopada 2012 r. oraz decyzje unijnego szczytu Rady Europejskiej z 22 maja 2013 r. w sprawie wyzwań i polityki w zakresie energii, na którym państwa członkowskie potwierdziły chęć ustanowienia w pełni funkcjonującego, wzajemnie połączonego i zintegrowanego wewnętrznego rynku energii do końca 2014 r. W efekcie Parlament Europejski w dniu 10 września 2013 r. przyjął rezolucję $\mathrm{w}$ sprawie uruchomienia wewnętrznego rynku energii ${ }^{37}$.

\section{3) Rola Parlamentu Europejskiego w rozwoju polityki klimatycznej UE}

Traktat o funkcjonowaniu Unii Europejskiej (TFUE), w tytule XX: Srodowisko w art. 191 wśród celów polityki UE uwzględnił dążenie do rozwiązywania regionalnych lub światowych problemów $w$ dziedzinie środowiska, w szczególności zwalczania zmian klimatu. Artykuły 191-193 TFUE stały się fundamentem wspólnotowego działania na rzecz polityki klimatycznej i stanowią umocowanie traktatowe dla inicjatyw legislacyjnych podejmowanych przez Komisję. Propozycje te są następnie analizowane i zatwierdzone przez Radę i Parlament Europejski, zgodnie ze zwykłą procedurą ustawodawcząą

Dnia 23 stycznia 2008 r. Komisja Europejska przedstawiła pakiet energetyczno-klimatyczny, który został zatwierdzony w dniach 11-12 grudnia 2008 r. przez Radę Europejską $\mathrm{w}$ trakcie prezydencji francuskiej ${ }^{39}$, a następnie przyjęty przez Parlament

2009/73/WE z dnia 13 lipca 2009 r. dotycząca wspólnych zasad rynku wewnętrznego gazu ziemnego i uchylająca dyrektywę 2003/55/WE; Rozporządzenie Parlamentu Europejskiego i Rady 713/2009/ WE z dnia 13 lipca 2009 r. ustanawiające Agencję ds. Współpracy Organów Regulacji Energetyki; Rozporządzenie Parlamentu Europejskiego i Rady 714/2009/WE z dnia 13 lipca 2009 r. w sprawie warunków dostępu do sieci w odniesieniu do transgranicznej wymiany energii elektrycznej i uchylające rozporządzenie 1228/2003 WE; Rozporządzenie Parlamentu Europejskiego i Rady 715/2009/WE z dnia 13 lipca 2009 r. w sprawie warunków dostępu do sieci przesyłowych gazu ziemnego i uchylające rozporządzenie 1775/2005/WE.

36 Regulation (EC) No. 714/2009 of the European Parliament and of the Council of 13 July 2009 on conditions for access to the network for cross-border exchanges in electricity and repealing Regulation (EC) No. 1228/2003, Official Journal of the European Union, L 211/15, 14 VIII 2009; Regulation (EC) No. 715/2009 of the European Parliament and of the Council of 13 July 2009 on conditions for access to the natural gas transmission networks and repealing Regulation (EC) No. 1775/2005, Official Journal of the European Union, L 211/36, 14 VIII 2009.

37 Making the internal energy market work, European Parliament resolution 2013/2005(INI).

$38 \mathrm{Z}$ wyłączeniem zagadnień wskazanych w ust. 2 art. 192, w których przewidziano specjalną procedurę prawodawczą.

39 Presidency Conclusions, European Council 11-12 December 2008, Brussels, 13 II 2009 (OR, fr). 
Europejski w dniu 17 grudnia 2008 r. ${ }^{40}$ Pakiet, który włączył politykę klimatyczną w obszar energii, zakładał realizację ambitnych zobowiązań w dziedzinie energii i klimatu (zadeklarowanych w marcu 2007 r.):

- nowelizacji europejskiego systemu handlu uprawnieniami do emisji (ETS),

- zmniejszenia emisji gazów cieplarnianych z sektorów nieobjętych ETS, takich jak transport, mieszkalnictwo, rolnictwo i odpady,

- związania krajowych celów w zakresie OZE,

- wychwytywania i składowania dwutlenku węgla.

Przedstawiając w styczniu 2007 r. założenia pakietu klimatyczno-energetycznego, Komisja Europejska de facto wyodrębniła politykę klimatyczną z polityki środowiskowej, a jednocześnie związała aspekty klimatyczne z polityką energetyczną ${ }^{41}$.

Pakiet energetyczno-klimatyczny zakładał realizację ambitnych zobowiązań w dziedzinie energii i klimatu (potocznie określane mianem „3×20”), w tym zmniejszenie emisji gazów cieplarnianych (GHG) co najmniej o 20\% w stosunku do roku 1990, i nowelizację Europejskiego Systemu Handlu Uprawnieniami do Emisji (European Union Emissions Trading System - EU ETS). System ten stał się głównym mechanizmem polityki przeciwdziałania zmianom klimatu w Unii. EU ETS opiera się na założeniu „wychwytywanie-handel" realizowanym na poziomie przedsiębiorstw zobowiązanych do zakupu zezwoleń na emisję dwutlenku węgla $\left(\mathrm{CO}_{2}\right)$ i innych gazów cieplarnianych w ramach odgórnie ustalonego limitu dostępnych uprawnień do emisji. Uczestnictwo przedsiębiorstw w sektorach objętych kontrolą emisji jest obowiązkowe, a system nadzorowany przez KE zakłada sankcje i zobowiązanie do zakupu brakujących uprawnień (jedno zezwolenie daje prawo do wyemitowania $\left.\mathrm{t} / \mathrm{CO}_{2}\right)^{42}$. Celem systemu handlu emisjami jest stworzenie bodźców finansowych mobilizujących obniżenie emisji $\mathrm{CO}_{2}$.

Aspiracje Komisji Europejskiej w kierunku przeciwdziałania zagrożeniom klimatu sięgały dalej niż cele określone w pakiecie energetyczno-klimatycznym. W marcu 2011 r. KE przyjęła plan działania prowadzący do przejścia na konkurencyjną gospodarkę niskoemisyjną do 2050 r., a w połowie grudnia 2011 r. zaprezentowała nowy strategiczny dokument Energy Roadmap 2050, który zakłada do 2050 r. redukcję emisji

40 EP Seals Climate Change Package, European Parliament, 17 XII 2008, [online] http://www.europarl. europa.eu/sides/getDoc.do?pubRef=-//EP//TEXT+IM-PRESS+20081208BKG44004+0+DOC $+\mathrm{XML}+\mathrm{V0} / / \mathrm{EN}, 30 \mathrm{VI} 2015$.

41 Wspólnotowe akty prawne wchodzące w skład pakietu energetyczno-klimatycznego: Dyrektywa Parlamentu Europejskiego i Rady 2009/29/WE w celu usprawnienia i rozszerzenia wspólnotowego systemu handlu uprawnieniami do emisji gazów cieplarnianych (tzw. dyrektywa EU ETS); Decyzja Parlamentu Europejskiego i Rady nr 2009/406/WE w sprawie wysiłków podjętych przez państwa członkowskie, zmierzających do zmniejszenia emisji gazów cieplarnianych w celu realizacji do roku 2020 zobowiązań Wspólnoty dotyczących redukcji emisji gazów cieplarnianych (tzw. decyzja non-ETS); Dyrektywa Parlamentu Europejskiego i Rady 2009/31/WE w sprawie geologicznego składowania dwutlenku węgla (tzw. dyrektywa CCS); Dyrektywa Parlamentu Europejskiego i Rady 2009/28/WE w sprawie promowania stosowania energii ze źródeł odnawialnych (tzw. dyrektywa OZE); Decyzja KE z dnia 24 grudnia 2009 r. ustalająca wykaz sektorów i podsektorów uważanych za narażone na znaczące ryzyko ucieczki emisji.

42 Uprawnienie do emisji jest to wielkość odpowiadająca ekwiwalentowi 1 tony $\mathrm{CO}_{2}$. 
gazów cieplarnianych GHG o 80\% poniżej poziomu z roku $1990^{43}$. Oznacza to dekarbonizację (odejście od węgla) w produkcji energii elektrycznej w UE, co ma przynieść niemal całkowity brak emisji $\mathrm{CO}_{2}$ w tym sektorze (redukcja o $96-99 \%$ w stosunku do roku 1990$)^{44}$. Dokument promuje budowę gospodarki o niskim poziomie wykorzystania węgla (low-carbon economy), zawężając cele polityki klimatycznej z redukcji emisji $\mathrm{CO}_{2}$ (gospodarki niskoemisyjnej, low-emission economy) do ograniczenia konsumpcji węgla jako źródła energii. Parlament Europejski poparł przedstawiony przez Komisję plan działania na rzecz wprowadzenia konkurencyjnej gospodarki niskoemisyjnej do 2050 r. wraz z jego poszczególnymi etapami redukcji emisji ${ }^{45}$.

W marcu 2013 r. KE opublikowała Zieloną Księgę na temat ram polityki w zakresie klimatu i energii, w której przeniosła w ślad za strategią do 2050 r. cel redukcji o 40\% emisji GHG do roku 2030 ${ }^{46}$. Dokument zwracał uwagę na kwestię konkurencyjności gospodarki unijnej i był wyrazem konsekwencji UE w dążeniu do budowy gospodarki niskoemisyjnej.

Zarówno Parlament Europejski ${ }^{47}$, jak i Rada Europejska podczas szczytu w dniach 20-21 marca 2014 r. poparty kierunki zaproponowane przez KE.

W trzecim okresie rozliczeniowym, od 2013 r., kiedy zaczął obowiązywać pełny aukcjoning, system handlu uprawnieniami do emisji okazał się mało efektywny wobec niskich cen uprawnień do emisji GHG. Nie zachęcało to przedsiębiorstw do inwestycji w zmniejszenie energochłonności i kosztowne niskoemisyjne technologie produkcji energii ${ }^{48}$. Toteż, przychylając się do propozycji KE, Parlament Europejski 3 lipca 2013 r. przegłosował tzw. backloading, czyli zawieszenie części aukcji uprawnień do emisji $\mathrm{CO}_{2}^{49}$. Oznaczało to przesunięcie $900 \mathrm{mln}$ uprawnień z lat 2014-2016 na okres 2019-2020, dzięki któremu ceny za jednostkę do emisji (EUA) mają systematycznie ro-

43 Impact Assessment. Communication from the Commission to the Council, the European Parliament, the European Economic and Social Committee and the Committee of the Regions, Energy Roadmap 2050, European Commission Staff Working Paper 2011, part 2/2, s. 36.

44 Tamże.

45 Rezolucja Parlamentu Europejskiego z dnia 15 marca 2012 r. w sprawie planu dziatania prowadzacego do przejścia na konkurencyjna gospodarkę niskoemisyjna do $2050 \mathrm{r}$. (2011/2095(INI)).

46 Zielona Ksiega Ramy polityki w zakresie klimatu i energii do roku 2030, COM (2013) 169 final, Bruksela, 27 III 2013.

47 Rezolucja Parlamentu Europejskiego z dnia 14 marca 2013 r. w sprawie planu dziatania w zakresie energii do roku 2050 - przysztość z energia (2012/2103 (INI)).

48 System handlu uprawnieniami do emisji w UE funkcjonuje od 2005 r., a jego całkowite wprowadzenie podzielono na trzy okresy rozliczeniowe: 2005-2007, 2008-2012 i po $2013 \mathrm{r}$.

49 Poprawka przyjęta przez Parlament Europejski w dniu 3 lipca 2013 r. w sprawie wniosku dotyczacego decyzji Parlamentu Europejskiego i Rady zmieniajacej dyrektywę 2003/87/WE w celu wyjaśnienia przepisów dotyczacych harmonogramu aukcji uprawnień do emisji gazów cieplarnianych (COM(2012)0416 C7-0203/2012 - 2012/0202(COD)), 3 VII 2013. Parlament Europejski ostatecznie zatwierdził zamrożenie aukcji $900 \mathrm{mln}$ pozwoleń na emisję $\mathrm{CO}_{2}$ w dniu 10 grudnia 2013 r., zob.: Rezolucja ustawodawcza Parlamentu Europejskiego z dnia 10 grudnia 2013 r. w sprawie wniosku dotyczacego decyzji Parlamentu Europejskiego i Rady zmieniajacej dyrektywę 2003/87/WE w celu wyjaśnienia przepisów dotyczacych harmonogramu aukcji uprawnień do emisji gazów cieplarnianych (COM(2012)0416 - C7$-0203 / 2012-2012 / 0202(C O D))$. 
snąć. Ostatecznie propozycja została przyjęta przez Radę 10 grudnia 2013 r. ${ }^{50}$ Zaproponowany przez Komisję Europejską backloading uzyskał poparcie wszystkich państw członkowskich UE z wyjątkiem Polski, która wskazywała, że to nieuzasadniona ingerencja w rynek, mogąca spowodować odejście od rynkowego charakteru systemu EU ETS ${ }^{51}$.

Parlament Europejski poparł też długofalowe działania na rzecz zaostrzenia celów redukcyjnych polityki klimatycznej UE, uchwalając 5 lutego 2014 r. rezolucję wspierającą projekt nowych ram klimatycznych 2020-2030 (m.in.: redukcję $\mathrm{CO}_{2}$ o 40\% wobec 1990 r. - co oznaczało podwojenie celu pakietu energetyczno-klimatycznego - oraz wzrost udziału OZE do $30 \%$ w całkowitej końcowej wykorzystywanej energii ${ }^{52}$. W ten sposób PE zaaprobował kierunki reformy systemu handlu uprawnieniami do emisji ${ }^{53}$.

Nowe progi redukcyjne zostały przyjęte na szczycie Rady Europejskiej w dniach 23-24 października 2014 r., zakładając ograniczenie emisji GHG UE do 2030 r. o 40\% wobec 1990 r. oraz wzrost udziału źródeł odnawialnych o 27\% dla całej UE (nie państw członkowskich) i taki sam cel poprawy efektywności energetycznej do 2030 r. $^{54}$ Postulaty dekarbonizacji rodzą jednak silny opór państw, których sektor energetyczny zdominowany jest przez węgiel, uzasadniając, iż zaostrzanie celów redukcyjnych GHG odbije się negatywnie na konkurencyjności sektora energetycznego i całych gospodarek opartych na węglu ${ }^{55}$.

\section{WNIOSKI}

Parlament Europejski niezmiennie wyraża swoje zdecydowane poparcie dla rozwoju wspólnej polityki energetycznej. Udział Parlamentu w procesie uwspólnotowienia sektora energetycznego i zapewnienia bezpieczeństwa energetycznego całej

50 Decyzja Parlamentu Europejskiego i Rady nr 1359/2013/UE z dnia 17 grudnia 2013 r. zmieniająca dyrektywę 2003/87/WE w celu wyjaśnienia przepisów dotyczących harmonogramu aukcji uprawnień do emisji gazów cieplarnianych, Official Journal, L 343/1, 19 XII 2013.

51 Diariusz z prackomisji senackich, 18 III 2014, [online] http://www.senat.gov.pl/diariusz/posiedzenia-komisji/art,6260,18-marca-2014-r-.html, 15 VI 2014.

52 Rezolucja Parlamentu Europejskiego $z$ dnia 5 lutego 2014 r. w sprawie ram polityki $w$ zakresie klimatu i energii do roku 2030 (2013/2135(INI)).

53 W styczniu 2014 r. KE zaproponowała nowe założenia pakietu energetyczno-klimatycznego i reformy EU ETS poprzez ustanowienie rezerwy stabilności rynkowej (Market Stability Reserve) na początku kolejnego okresu handlu uprawnieniami w 2021 r. Rezerwa (pula uprawnień do emisji $\mathrm{CO}_{2}$ miałaby być corocznie zmniejszana poprzez wprowadzenie do rezerwy $12 \%$ całkowitej liczby uprawnień) ma rozwiązać problem nadwyżki uprawnień do emisji i spowodować wzrost ich cen.

54 Conclusions on 2030 Climate and Energy Policy Framework, European Council 23-24 October 2014, SN 79/14, Brussels, 23 X 2014.

55 Przykładem wpływu Parlamentu Europejskiego na rozwój polityki energetycznej UE jest oddziaływanie Komisji Ochrony Środowiska Naturalnego, Zdrowia Publicznego i Bezpieczeństwa Żywności (ENVI) w sprawie skutków tzw. szczelinowania hydraulicznego, doprowadzając do uchwalenia przez Parlament Europejski obowiązku przeprowadzania przez inwestorów pełnej oceny oddziaływania na środowisko już na wstępnym etapie poszukiwawczym gazu z łupków (co może rodzić wzrost kosztów i opóźniać inwestycje). 
Wspólnoty jest ogromny z uwagi na jego pozycję i umocowanie w strukturze unijnych instytucji. Parlament Europejski - poprzez współudział w tworzenie energy acquis - w ramach zwykłej procedury ustawodawczej jest pełnoprawnym podmiotem odpowiadającym za kształt unijnego porządku prawnego, a poglądy deputowanych oddziałują w sposób pośredni oraz bezpośredni na kształt prawa i polityki UE. Stałe komisje parlamentarne ITRE i ENVI silnie wpływają na przyjmowane rozwiązania legislacyjne, które tworzą porządek prawny w sektorze energetycznym i wpływają na kształt polityki energetyczno-klimatycznej UE. Poprzez pośrednią inicjatywę ustawodawczą Parlament Europejski staje się także aktywnym kreatorem politycznych inicjatyw KE.

PE nie jest uprawniony do samodzielnego przyjmowania aktów prawnych UE, a jedynie do uczestniczenia w procesie prowadzącym do ich przyjęcia. Funkcja prawodawcza polega na wpływaniu na proces prawotwórczy rozwoju unijnych polityk. Ustanowienie traktatem lizbońskim podstaw prawno-traktatowych dla współpracy energetycznej pozwoli na dalszy rozwój prawodawstwa pochodnego (wtórnego) w tym obszarze. Traktat lizboński wprowadził także zasadę „solidarności energetycznej” między państwami członkowskimi. Parlament Europejski poprzez uczestnictwo w procesie ustawodawczym - akty prawa wtórnego związane z budową jednolitego rynku energii - wpływa na poprawę bezpieczeństwa energetycznego całej UE oraz przyczynia się do wdrożenia wiarygodnych mechanizmów reagowania kryzysowego zapewniających całej UE współdziałanie w nagłych przypadkach. Parlament wspiera też rozbudowę europejskiej infrastruktury energetycznej (przesyłu, magazynowania), zdając sobie sprawę, że stworzenie europejskiego rynku energii jest uzależnione od zapewnienia wydajnych połączeń między krajami (transeuropejskie sieci energetyczne TEN-E). Odgrywa zatem niezwykle istotną rolę w przyjmowaniu środków legislacyjnych UE, często pełniąc funkcję „akuszera” pomysłów i inicjatyw Komisji Europejskiej.

Wysiłki KE w procesie budowy wewnętrznego rynku energetycznego wspierane przez Parlament Europejski doprowadziły do stopniowej ewolucji sektora energii elektrycznej i gazu - od rynków narodowych z dominującą pozycją pionowo zintegrowanych monopoli do modelu uwzględniającego wolną konkurencję na poziomie detalicznym, stworzenie niezależnych operatorów systemu i rozdział właścicieli produkcji od przesyłu i dystrybucji oraz powołanie europejskiej agencji regulacyjnej ACER. Aktualne rozwiązania prawno-traktatowe uwzględniają wszystkie trzy elementy trójkąta energetycznego UE: bezpieczeństwo dostaw, konkurencyjność i zrównoważony rozwój. Parlament Europejski odgrywa ważną rolę na szczeblu ponadnarodowym w procesie uwspólnotowienia sektora energetycznego, nierzadko pełniąc funkcję politycznego forum budowy kompromisów niezbędnych do pogłębienia polityki energetycznej UE. Aktywnie uczestniczy także w rozwoju unijnej polityki energetyczno-klimatycznej. Oprócz udziału w tworzeniu prawa (kolejne dyrektywy dotyczące redukcji GHG, wzrostu udziału OZE i efektywności energetycznej), poprzez regularne debaty parlamentarne wyraża stanowisko w stosunku do podstawowych kwestii będących przedmiotem tworzonego międzynarodowego reżimu przeciwdziałania zmianom klimatu. 


\section{BIBLIOGRAFIA}

\section{Źródła}

Communication from the commission to the council and the European Parliament Completing the internal energy market Proposal for a Directive of the European Parliament and of The Council amending Directives 96/92/EC and 98/30/EC concerning common rules for the internal market in electricity and natural gas, COM (2001) 125 final, Brussels, 13 III 2001.

Community guidelines on trans-European energy networks, COM (93) 685 final, Brussels, 19 I 1994.

Conclusions on 2030 Climate and Energy Policy Framework, European Council 23-24 October 2014, SN 79/14, Brussels, 23 X 2014.

Decision no 1047/97/EC of the European Parliament and of the Council of 29 May 1997 amending Decision No 1254/96/EC laying down a series of guidelines for trans-European energy networks, Official Journal, L 152, 11 VI 1997.

Decision no 1364/2006/EC of the European Parliament and of the Council of 6 September 2006 laying down guidelines for trans-European energy networks and repealing Decision 96/391/EC and Decision no 1229/2003/EC, Official Journal, L 262, 22 IX 2006.

Decyzja Parlamentu Europejskiego i Rady nr 994/2012/UE z dnia 25 października 2012 r. w sprawie ustanowienia mechanizmu wymiany informacji wodniesieniu do umów międzyrzadowych $w$ dziedzinie energii między państwami cztonkowskimi a państwami trzecimi, Dz. U. UE 2012, 27 X, L 299/13.

Decyzja Parlamentu Europejskiego i Rady nr 1359/2013/UE z dnia 17 grudnia 2013 r. zmieniajaca dyrektywę 2003/87/WE w celu wyjaśnienia przepisów dotyczacych harmonogramu aukcji uprawnień do emisji gazów cieplarnianych, Official Journal, L 343/1, 19 XII 2013.

Decyzja Parlamentu Europejskiego i Rady ustanawiajaca mechanizm wymiany informacji w odniesieniu do umów międzyrządowych $w$ dziedzinie energii między państwami cztonkowskimi a państwami trzecimi, COM (2011) 540, 2011/0238 (COD), Bruksela, 7 IX 2011.

Diariusz $z$ prac komisji senackich, 18 III 2014, [online] http://www.senat.gov.pl/diariusz/ posiedzenia-komisji/art,6260,18-marca-2014-r-.html.

Directive 2003/54/EC of the European Parliament and of the Council of 26 June 2003 concerning common rules for the internal market in electricity, Official Journal, L 176/37, 15 VII 2003.

Directive 2003/55/EC of the European Parliament and of the Council of 26 June 2003 concerning common rules for the internal market in natural gas, Official Journal, L 176/57, 15 VII 2003.

Directive 2009/72/EC of the European Parliament and of the Council of 13 July 2009 concerning common rules for the internal market in electricity and repealing Directive 2003/54/EC, Official Journal of the European Union, L 211/5, 14 VIII 2009.

Directive 2009/73/EC of the European Parliament and of the Council of 13 July 2009 concerning common rules for the internal market in natural gas and repealing Directive 2003/55/EC, Official Journal of the European Union, L 211/94, 14 VIII 2009.

Directive 96/92/EC of the European Parliament and of the Council of 19 December 1996 concerning common rules for the internal market in electricity, Official Journal, L 027, 30 I 1997. 
Directive 98/30/EC of the European Parliament and of the Council of 22 June 1998 concerning common rules for the internal market in natural gas, Official Journal, L 204, 21 VII 1998.

EP Seals Climate Change Package, European Parliament, 17 XII 2008, [online] http://www. europarl.europa.eu/sides/getDoc.do?pubRef=-//EP//TEXT+IM-PRESS+20081208BK $\mathrm{G} 44004+0+\mathrm{DOC}+\mathrm{XML}+\mathrm{V0} / / \mathrm{EN}$.

European Parliament resolution of 12 June 2012 on Engaging in energy policy cooperation with partners beyond our borders. A strategic approach to secure, sustainable and competitive energy supply (2012/2029(INI)), [online] http://www.europarl.europa.eu/sides/getDoc.do?pubRef $=-/ / \mathrm{EP} / / \mathrm{TEXT}+\mathrm{TA}+\mathrm{P} 7-\mathrm{TA}-2012-0238+0+\mathrm{DOC}+\mathrm{XML}+\mathrm{V0} / / \mathrm{EN}$.

Impact Assessment. Communication from the Commission to the Council, the European Parliament, the European Economic and Social Committee and the Committee of the Regions, Energy Roadmap 2050, European Commission Staff Working Paper 2011, part 2/2.

Making the internal energy market work, European Parliament resolution 2013/2005(INI).

On the state of liberalisation of the energy markets, Second Report from the Commission to the Council and the European Parliament, COM (1999) 198 final, Brussels, 4 V 1999.

Oświadczenie Komisji w sprawie konkurencji w odniesieniu do motywu 45, [online] http:// www.europarl.europa.eu/sides/getDoc.do?pubRef=-//EP//TEXT+TA+P7-TA-2010$-0322+0+\mathrm{DOC}+\mathrm{XML}+\mathrm{V} 0 / / \mathrm{PL}$.

Poprawka przyjęta przez Parlament Europejski w dniu 3 lipca 2013 r. w sprawie wniosku dotyczącego decyzji Parlamentu Europejskiego i Rady zmieniajacej dyrektywę 2003/87/WE w celu wyjaśnienia przepisów dotyczacych harmonogramu aukcji uprawnień do emisji gazów cieplarnianych (COM(2012)0416 - C7-0203/2012 - 2012/0202(COD)), 3 VII 2013.

Presidency Conclusions, European Council 11-12 December 2008, Brussels, 13 II 2009 (OR, fr). Proposal for a EP and Council decision 94/0009 (COD) laying down a series of guidelines on trans-European energy networks.

Proposal for a Council decision 94/0010 (SYN) laying down a series of measures aimed at creating a more favourable context for the development of trans-European networks in the energy sector.

Regulation (EC) No. 714/2009 of the European Parliament and of the Council of 13 July 2009 on conditions for access to the network for cross-border exchanges in electricity and repealing Regulation (EC) No. 1228/2003, Official Journal of the European Union, L 211/15, 14 VIII 2009.

Regulation (EC) No. 715/2009 of the European Parliament and of the Council of 13 July 2009 on conditions for access to the natural gas transmission networks and repealing Regulation (EC) No. 1775/2005, Official Journal of the European Union, L 211/36, 14 VIII 2009.

Rezolucja Parlamentu Europejskiego z dnia 5 lutego 2014 r. w sprawie ram polityki $w$ zakresie klimatu i energii do roku 2030 (2013/2135(INI)).

Rezolucja Parlamentu Europejskiego z dnia 5 lipca 2011 r. w sprawie priorytetów w odniesieniu do infrastruktury energetycznej na $2020 \mathrm{r}$. i w dalszej perspektywie (2011/2034(INI)).

Rezolucja Parlamentu Europejskiego z dnia 14 marca 2013 r. w sprawie planu dziatania w zakresie energii do roku 2050 - przysztość z energia (2012/2103 (INI)).

Rezolucja Parlamentu Europejskiego z dnia 15 marca 2012 r. wsprawieplanu dziatania prowadzacego do przejścia na konkurencyjna gospodarkę niskoemisyjna do 2050 r. (2011/2095(INI)). 
Rezolucja Parlamentu Europejskiego z dnia 17 września 2009 r. w sprawie zewnętrznych aspektów bezpieczeństwa energetycznego, Dz. U. 2008, 28 VIII, C 219 E.

Rezolucja Parlamentu Europejskiego z dnia 26 września 2007 r. w sprawie wspólnej europejskiej polityki zagranicznej $w$ dziedzinie energetyki (2007/2000(INI)).

Rezolucja ustawodawcza Parlamentu Europejskiego i Rady z dnia 10 grudnia 2013 r. wniosku dotyczacego decyzji Parlamentu Europejskiego i Rady zmniejszajacej dyrektywe 2003/87/WE w celu wyjaśnienia przepisów dotyczących harmonogramu redukcji uprawnień do emisji gazów cieplarnianych (COM (2012) 0416 - C7-0203/2012 - 2012/0202(COD)).

Rozporzadzenie (UE) 994/2010 z dnia 20 października 2010 roku w sprawie środków zapewniajacych bezpieczeństwo dostaw gazu ziemnego o i uchylenia dyrektywy Rady 2004/67/WE, L 295/1, 12 XI 2010.

Rozporzadzenie (WE) nr 1228/2003 Parlamentu Europejskiego i Rady z dnia 26 czerwca 2003 r. $w$ sprawie warunków dostępu do sieci $w$ odniesieniu do transgranicznej wymiany energii elektrycznej, L 176/1, 15 VII 2003.

Rozporzadzenie (WE) nr 1775/2005 Parlamentu Europejskiego i Rady z dnia 28 września 2005 $r$, w sprawie warunków dostępu do sieci przesytowych gazu ziemnego, L 289/1, 3 XI 2005.

The EU Energy Policy. Engaging with Partners beyond Our Borders, COM (2011) 539 final, Brussels, 7 IX 2011.

Zielona Księga Ramy polityki w zakresie klimatu i energii do roku 2030, COM (2013) 169 final, Bruksela, 27 III 2013.

\section{Monografie}

Derdevet M., L’Europe en panne d'énergie. Pour une politique énergétique commune, Paris 2009.

\section{Artykuły}

Parmigiani L., Gas Routes to Europe. Real Needs and Political Jockeying, Institut Français des Relations Internationales, 16 IV 2012, [online] http://www.ifri.org/sites/default/files/atoms/ files/actuellelppipelinesvf20120413.pdf.

Renssen van S., External Energy Policy. Brussels Takes Charge, „European Energy Review” 2011, 12 IX.

Dr hab. Tomasz MŁYNARSKI - politolog, adiunkt w Katedrze Stosunków Międzynarodowych i Polityki Zagranicznej INPiSM UJ. Stypendysta l'Institut d'Études Politiques w Paryżu oraz Sorbony, specjalizuje się w zagadnieniach dotyczących problematyki bezpieczeństwa energetycznego, instytucjonalizacji bezpieczeństwa UE i współczesnej polityki zagranicznej oraz bezpieczeństwa Francji. Autor monografii i artykutów, m.in. Francja wobec gtównych problemów reformy instytucjonalnej Unii Europejskiej w XXI w. (2006), Bezpieczeństwo energetyczne w pierwszej dekadzie XXI w. Mozaika interesów i geostrategii (2011), Francja w procesie uwspólnotowienia bezpieczeństwa energetycznego i polityki klimatycznej Unii Europejskiej (2013). 